\title{
Transforming Charcoals into Diamonds? Exploring Time Pressured Assessment as a Tool of Transformative Education in Law Classrooms
}

\author{
Shahrul Mizan Ismail
}

\begin{abstract}
Recent trend seems to indicate that undergraduate law students nowadays are so used to having several weeks or more to complete their assignments, most of the time guided by their instructor's feedback while completing them. This is in addition to 'spoon-feeding', 'powerpoint slides-based', 'one way street', series of lectures done on a weekly basis to help them prepare for their final semester exams. This practice however runs counter to the reality of the legal profession where lawyers constantly work in stressful environments, under time pressure, while juggling multiple tasks involving crucial financial and live issues of their clients. This action research paper investigates the benefits and impacts of using time pressured assessment as a tool of transformative education to produce a more practice-ready graduate as expected by the industry. Using qualitative approach, it explores the concept of transformative education, and examines the use of 'pressure' element to prepare students for the real world, and teach them the fundamental lawyering skills needed for legal practice. At a time of declining resilience of a law graduates, a competitive legal job market, and the ever high expectation of practice-ready law graduates, this paper is paramount in answering whether law schools should reconsider its curriculum to be more transformative by adding the element of time pressured assessment.
\end{abstract}

Keywords: Law students, qualitative, time pressured, transformative education, legal practice

\section{INTRODUCTION}

During an era of declining versatility of law graduates and a focused legitimate activity advertise, law graduates should adjust with fast change and show administration in their jobs as entering experts (Orfus, 2008). Ostensibly, in the present focused and globalized society, imagination and administration is a higher priority than any time in recent memory. Making a domain intended to amplify transformative training may help college understudies alter all the more promptly to a quick changing work environment and give instruments to future law graduates confronting difficulties in the midst of changes. Law understudies, who likewise take different information based courses, study many tedious specialized and down to earth subjects that require hands-on activity and practice. It is a test for law understudies to oversee courses, assignments, relaxation exercises, and above all, rest. Regardless of whether an understudy capitulates to stalling when looked with pressure, which may cause learning difficulties and differ from reality of the legal profession, is an issue worth exploring. The reality of the legal profession where lawyers

Revised Manuscript Received on November 11, 2019.

ShahrulMizan Ismail, Assoc. Prof. Dr. ShahrulMizan Ismail, National University of Malaysia constantly work in stressful environments, under time pressure, while juggling multiple tasks involving crucial financial and live issues of their clients.

\section{OBJECTIVE}

The main purpose of this study is to explore whether law schools should reconsider its curriculum to be more transformative by adding the element of time pressured assessmentto produce a more practice-ready graduate as expected by the industry.

\section{LITERATURE REVIEW}

Exhaust and time pressure are the beginnings of weight (Freedman and Edwards, 1988). Weight results from contrasts among requests and qualities, with more noteworthy contrasts bringing about bigger weights (Schuler, 1979, Noniset al., 1998). Understudies make some restricted memories for learning at college, yet have numerous courses and exercises; every understudy needs to deal with their learning time while concentrating on explicit (center) courses and consigning different less-significant courses to the foundation. Noniset al., (1998) imagined that the issue of time the board isn't that understudies have an excessive amount of work, however deficient time to would what they like to do most. Along these lines, understudies without time the board abilities may usually experience issues finishing assignments inside a restricted timeframe. Great time the executives empowers understudies to work all the more effectively, complete assignments or objectives on schedule, and accomplish more with the time they have.

Notwithstanding, law understudies take a wide range of subjects and the kind of learning required for the law subjects are unique in relation to the learning required for normal subjects which it require since quite a while ago points of view and for the most part have severe cutoff times. Accordingly, an understudy's time is once in a while divided and they are not ready to utilize it viably. This can bring about a lot of weight, which could prompt tarrying. Along these lines, so as to utilize time constrained appraisal as device of transformative training in law study halls, a couple of things must be thought about.

Kocher et al., (2013) and Bollard et al., (2007) find that time pressure changes particular tempers toward possibility. Time pressure in like manner can change solitary lead by rising physiological weight, which along these lines assembles danger taking (Putman et al., 2010; Buckertet al., 2014) and impedes imperative thinking (Lederet al., 2013).

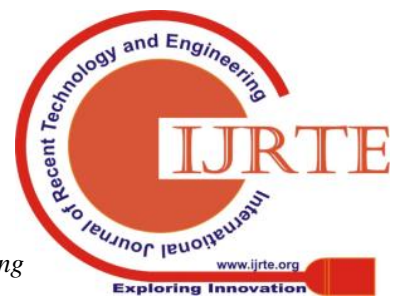


Additionally, time force was viewed as a convincing methodology to refocus understudies yet expelling the advancement and unpredictability of such contemplations made them produce work that was aphorism and unexceptional (Tsai et al., 2017).

Moreover, an examination coordinated by Orfus (2008) where the subjects in the time pressure formed were told they simply had a limited proportion of time to complete the task and were constantly recollected this time pressure, showed that it can influence a mental endeavor execution (Bembenutty, 2009). Regardless, time pressure alone didn't make liberal augmentations in imaginativeness scores. Time pressure decidedly influenced creative mind scores when gotten together with positive emotions. Tsai et al., (2017) fight that by making a circumstance where understudies show positive sentiments and by furthermore applying moderate time pressure, teachers can assist work with increasing understudies' imaginative thinking. It is in like manner endorse that speakers at first empower a ton of time for understudies to grasp the basic thoughts of the instructive program, and a short time later use time pressure during understudies' work time (Tsai et al., 2017). Extravagant pretense can be made by game-based educating or using gratified extended reality can convey circumstances in which understudies show positive feelings.Moreover, various past investigations have uncovered the scholastic and inventive advantages of positive feelings. Tsai et al., (2017) expressed that, even notwithstanding misfortune,positive feelings can assist understudies with reacting serenely to negative musings or circumstances, and in this manner stay enthusiastic about their objectives. The notable expand and-fabricate hypothesis recommends that constructive feelings or broadened thinking capacities animate more extensive individual memory information and make psychological changes, in this manner advancing innovative reasoning. Past examination demonstrate the viability of joining positives feelings and time pressure in homerooms to improve the results of inventive reasoning based instructing. This can be applied in law study halls to improve the lawyering aptitudes and planning practiceprepared law graduates to the truth of the lawful calling where legal advisors always work in unpleasant conditions, under time pressure, while shuffling different undertakings including significant money related and live issues of their customers

\section{METHODOLOGY}

A Google drive was set up with 114 envelopes (7 unique assignments in 114 organizers). 114 last year law understudies were chosen and given 4 hours to finish the errands independently in which experts from different foundation, for example, legal counselor, officer, and speaker were welcome to watch. The information was gathered by utilizing the understudy criticism and perception by experts following 4 hours of time compelled task were given.

\section{FINDING AND DISCUSSION}

In light of 114 inputs got from the understudies, for the most part 82 criticisms were sure and just 32 inputs were negative. From the rate perspective, $72 \%$ were concur that by utilizing time-compelled in finishing an assignment, would bring the best out of them. Then just $28 \%$ were not concur with the evaluation and felt that the appraisal were marginally misrepresented contrasted with genuine as a legal advisor. This outcomes indicated that the utilization of 'pressure' component in finishing an errand would push them harder and get unforeseen outcomes task. Dominant part of the understudy imagine that by experiencing time compelled appraisal, they had the chance to test their capacities in lawyering aptitudes and points of confinement.

Additionally, 32 understudies felt that time-forced were 'damnation' for them. They felt the appraisal just exercise in futility and not mirror the genuine idea of filling in as an attorney. Anyway this can be refuted and abstract. Be that as it may, despite everything they function admirably under strain and figure out how to finish the undertaking inside 4 hours. They contend that despite the fact that they function admirably under strain, their imagination side gradually blurred and nature of execution were exacerbate. In light of the criticism, primary concern that the creator can see was the understudies were not so much happy with their nature of execution under severe time pressure. They contend that time constrained evaluation were not genuinely mirror the legitimate practice condition. This demonstrated the law understudies were not uncovered enough with mechanical preparing and lawful work on during their investigations in the college.

Earlier research on execution impacts has exhibited unmistakably that time pressure builds the pace of individual and gathering execution (Kelly \&Karau, 1993, 1999). Be that as it may, results have been considerably less reliable on the nature of execution, with proof of a positive relationship (Kelly \&Karau, 1999), a negative relationship (Kelly and McGrath, 1985), a curvilinear relationship showing an ideal degree of moderate time pressure (Isenberg, 1981), and no relationship by any means (Bassett, 1979). The understudy were entrusted to deal with their time utilizing their own inventiveness in 4 hour time allotment Fundamentally, most of this assessment has focused on the presentation of modestly clear tasks instead of assignments requiring innovativeness. The discoveries demonstrated that time pressure undermines the perspectives that add to imaginative yield in law understudies. In spite of past research indicating that time-compelled understudies may work quicker, accomplish more, and improve chip away at direct errands, our discoveries demonstrated that they will be more averse to think inventively on the assignment. Additionally, the time pressure results propose conceivable combined impacts after some time. Throughout an appraisal, incessantly significant levels of time weight might be related with constantly lower commitment in inventive reasoning.

Along these lines, in spite of the way that time weight may lead understudy to work all the more constantly, it appears to moreover make them less slanted to administer their emotional resources for inventive reasoning.Our fundamental discovering is predictable with three past investigations on time pressure and imaginative results (Amabile et al., 1996; Andrews and Smith, 1996; Kelly and McGrath, 1985). Albeit past research on time weight and imagination for the most part proposes a negative relationship, the assemblage of observational proof is a long way from powerful. Additionally, none of the couple of past examinations on 
time weight and inventiveness has displayed a solid hypothetical structure for seeing how time weight may have its belongings. In particular, no exploration has straightforwardly inspected the procedure that apparently underlies the generation of innovative work and inventive reasoning. Be that as it may, enormous measure of understudy were accounted for to felt energized while doing the time-compelled appraisal and bring their imagination side to another level. Positive condition with no other weight beside time oblige, make the understudy felt excited while carrying out different responsibilities and discovered different issue, for example, issue with the printer and their workstation continued slamming.

Morely, dominant part of the understudy felt that the time constrained evaluation was extraordinary encounters even extreme minority doesn't care for it. Minority of the understudy would prefer to have an assessment test than experiencing time compelled appraisal once more. The dominant part recommends that the time span of 4 hours were insufficient and the nature of the work created were diminished. Positive and negative criticism from law understudies were emotional and they may have diverse idea about the evaluation over the course year on the grounds that the appraisal were done to set up the understudy with this present reality of upsetting lawful practice.

\section{CONCLUSION}

From the perspective of the diverse course years, because of first year law understudies simply finishing their semester with normal information and fundamental law courses, and venturing into the learning of expert and useful establishment law center courses, there might be adjustment issues; time pressures were noted when they confronted task cutoff times. This activity look into has instructed understudies to welcome the time, utilizing on the current assets and the most significant is to design and decide the work and major business of the student should do. This preparation will edify understudies on what to do to guarantee each understudy's exertion has fulfilled results. Thus, it is generally significant for graduate schools to reevaluate its educational program to be increasingly transformative by including the component of time forced assessment to get ready understudies for this present reality, show them the central lawyering abilities required for lawful practice and create a more practice-prepared alumni true to form by the business.

\section{ACKNOWLEDGEMENT}

The author might want to thank and recognize this is inquire about is bolstered by Center for Research and Instrumentation Management (CRIM) UKM under Research Grant No. KRA-007-2017 entitled 'Consolidating Heutagogical Components in Legal Education to 'Upset' Conventional Teaching Model: Developing Collaborative 'Strategic Met-Pokemon-Go' Game by means of Physical, Virtual and Augmented Reality Activities'..

\section{REFERENCES}

1.Amabile, T. M., Conti, R., Coon, H., Lazenby, J., and Herron, M. 1996. Surveying the workplace for innovativeness. Institute of Management Journal, 39: 1154-1184.
2.Andrews, J., and Smith, D. C. 1996. Looking for the showcasing creative mind: Factors influencing the innovativeness of advertising programs for develop items. Diary of Marketing Research, 33, 174-187

3.Bassett, G. A. 1979. An investigation of the impacts of errand objective and calendar decision on work execution. Hierarchical Behavior and Human Performance, 24: 202-227.

4.Bembenutty, H. 2009. Test nervousness and scholastic postponement of satisfaction, College Student Journal, vol. 43, no. 1, pp 10-21

5.Bollard, A., Liu, R., Nursimulu, A.D., Rangel, A., Bossaerts, P. 2007. Neurophysiological proof on impression of remuneration and hazard: Implications for exchanging under time pressure. Working paper, CalTech, Pasadena, CA

6.Buckert, M., Schwieren, C., Kudielka, B., and Fiebach, C. J. 2014. Intense pressure influences chance taking yet not equivocalness repugnance. Front. Neurosci. 8:82

7.Freedman, J. L., and Edwards, D. R. 1988. Time pressure, task execution, and happiness, In J. E. McGrath (Ed.), The social brain research of time: New points of view, Sage Publications, pp 113-133

8.Isenberg, D. J. 1981. A few impacts of time-pressure on vertical structure and basic leadership precision in little gatherings. Hierarchical Behavior and Human Performance, 27: 119-134.

9.Kelly, J. R., and Karau, S. J. 1993. Entrainment of imagination in little gatherings. Little Group Research, 24: 179-198.

10.Kelly, J. R., and Karau, S. J. 1999. Collective choice making: The impacts of introductory inclinations and time pressure. Character and Social Psychology Bulletin, 25: 1342-1354.

11. Kelly, J. R., and McGrath, J. E. 1985. Impacts of time breaking points and errand types on task execution and cooperation of four-man gatherings. Diary of Personality and Social Psychology, 49: 395-407.

12.Kocher, M. G., Pahlke, J. and Trautmann, S. T. 2013. Tempus Fugit: Time Pressure in Risky Decisions, Management Science, 59(10), 2380-2391

13.Leder, J., Häusser, J. An., and Mojzisch, A. 2013. Stress and key basic leadership in the excellence challenge game. Psychoneuroendocrinology, 38(9), 1503-1511

14.Nonis, S. A., Hudson, G. I., Logan, L. B., and Ford, C. W. 1998. Impact of apparent power after some time on undergrads' pressure and stressrelated results, Research in Higher Education, vol. 39, no 5, pp $587-$ 605

15.Orfus, S. 2008. The Effect Test Anxiety and Time Pressure on Performance, The Huron University College Journal of Learning and Motivation: Vol. 46: Issue 1, Article 7

16.Putman, P., Antypa, N., Crysovergi, P., and van der Does, W. A. 2010. Exogenous cortisol intensely impacts persuaded basic leadership in solid youngsters. Psychopharmacology 208, 257-263

17.Tsai, CY., Chang, YH., and Lo, CL., 2017. Learning Under Time Pressure: Learners Who Think Positively Achieve Superior Learning Outcomes from Creative Teaching Methods Using Picture Books. Thinking Skills and https://doi.org/10.1016/j.tsc.2017.11.003

\section{AUTHORS PROFILE}

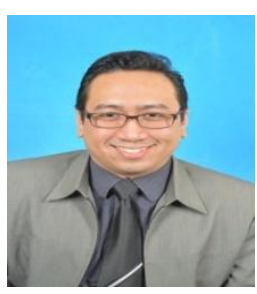

Assoc. Prof. Dr. ShahrulMizan Ismail

Associate Professor, Faculty of Law (FUU), National University of Malaysia (UKM), Malaysia (2016 - Present)

Area of specialization:

(1) International Human Rights Law;

(2) International Criminal Justice \& Armed Conflict);

(3) Civil Procedure;

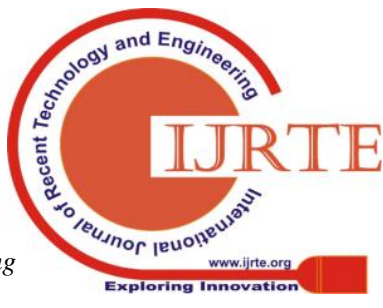

